\title{
Real Effective Exchange Rate and Export Performance: The Case of Sri Lanka
}

\section{S. D. Nilanka Chamindani ${ }^{12}$}

\begin{abstract}
This study examines the determinants of manufacturing exports of Sri Lanka with specific emphasis on the impact of the real effective exchange rate (REER). The hypothesis that persistent appreciation of the REER has negative implications on exports, when other determinants of manufacturing exports remain constant, is tested using the reduced form of the export equation with annual data for the period 1970-2014.The export equation is estimated using the Autoregressive Distributed Lag (ARDL) method. The results suggest that the REER is a key determinant of export performance of Sri Lanka. The world demand is also a contributory factor. If Sri Lanka takes corrective macroeconomic policy measures to maintain the REER at a realistic (market consistent) level and to cater to the upper income markets by improving the quality of products and linking with global supply chain networks, it would enable Sri Lanka to secure international competitiveness.
\end{abstract}

Key Words: Real Exchange Rate, Export Growth, Trade, Macro Economic Policy, Autoregressive Distributed Lags (ARDL) model

JEL Classification: C32, E58, F31, F41

\footnotetext{
${ }^{1}$ Senior Assistant Director of the Regional Development Department of the Central Bank of Sri Lanka.

${ }^{2}$ The author wishes to thank Professor Prema-chandra Athukorala at the Australian National University for his invaluable guidance to complete this research project.
} 


\section{Introduction}

The purpose of this study is to examine the determinants of manufacturing exports from Sri Lanka for the period 1970-2014. The study emphasizes on the impact of the Real Effective Exchange Rate (REER) on manufacturing exports. The REER is one of the prime determinants that are considered in designing policies to promote exports. It is computed by adjusting the trade weighted nominal exchange rate with relative prices between the exporting country and destination countries, and used to measure the relative profitability and competitiveness of exports. Exchange rate misalignment, that is, persistent appreciation of the real exchange rate relative to the equilibrium level, when other factors remain constant, has negative implications on exports (Edwards 1988).

Sri Lanka is an ideal case to examine the relationship between the REER and the performance of manufacturing exports, particularly for two reasons: First, due to the continuous drop in its share in the international market in recent years. Second, in the ongoing policy debate, the real exchange rate appreciation over the past 10 years has been highlighted as one of the key determinants for the reverse pattern of export diversification, which has been underpinned by inappropriate macroeconomic policies (Athukorala \& Jayasuriya 2015). However, this hypothesis has not yet been tested empirically and the main objective of this study is to fill this gap by testing this hypothesis.

There is substantial empirical literature on the relationship between the REER and the export performance in developing countries (Bilquees et al. 2010, Fang et al. 2006, Grobar 1993, Haddad \& Pancaro 2010, Hinkle \& Monteil 1999, Krugman 1989, Nkwelle 2007). The misalignment of the REER has been a source of serious economic distress for many developing countries (Edwards 1988, Shatz \& Tarr 2000). Notwithstanding the policy emphasis on export promotion, the only previous study relating to the export performance of Sri Lanka (Ekanayake et al. 1999) has taken the nominal exchange as the determinant of the expansion of exports. Moreover, there have been changes in the structure of the export sector performance over the last two decades, which require renewed research on the sector with a more realistic approach.

The current policy debate and decisive macroeconomic policy changes over the last decades provide ample space to analyse the impact of the REER on manufacturing exports. The purpose of this study is to examine the determinants of manufacturing exports from Sri Lanka, with specific focus on the REER. Accordingly, the study tests the hypothesis of whether persistent appreciation of the REER has an impact on the performance of manufacturing exports.

In order to test the hypothesis, this study employs a fully specified reduced form export equation to identify the determinants of the performance of manufacturing exports. The study analyses the manufacturing exports (excluding petroleum products) and disaggregates the total 
manufacturing exports to garment exports and other exports. Though the main focus is to examine the impact of the REER on the performance of exports, a bivariate model is not sufficient as many other factors, which cannot be captured by the REER variable, influence exports. Therefore, the REER variable is incorporated as the key explanatory variable, while other variables are included as controlled variables. In addition to the REER, this study takes into account the world demand for manufacturing exports, the impact of foreign direct investments, improvements in the production capacity overtime, the changes in trade related policy regimes and quota facility under the Multi Fiber Agreement (MFA) offered to garment exports.

The paper is organized as follows: Section Two gives a brief overview of the manufacturing sector, macroeconomic policy and changes in the real exchange rate relating to the performance of exports in Sri Lanka. Section Three presents the specification of the model. Data and sources are given in Section Four. Section Five describes the methodology, while the results and findings are discussed in Section Six, followed by the conclusion.

\section{Sri Lankan context}

Having identified the importance of promoting the export sector with increased private sector participation as the engine of growth, Sri Lanka introduced export- oriented policy reforms in 1977, marking a turning point in its economic history (Athukorala \& Rajapatirana 2000). This policy shift was subsequent to disastrous experiences that the nation encountered due to inward looking policies in a controlled regime with public sector dominance in economic activities. With the policy shift, the theme of the development strategy was to promote free trade with more industrial exports. An incentive package with infrastructure development and tax incentives was given to drive the private sector in line with the government development strategy.

Following the reforms, the export structure of Sri Lanka changed significantly, with manufactured goods becoming the most vibrant element. The country was able to achieve higher economic growth compared to the other developing countries in the region due to the fast expansion of the manufacturing exports. The rapidly growing manufacturing export sector also helped increase employment and reduce poverty in the country.

The degree of enthusiasm to promote manufacturing exports and sustain the pace of its performance changed from time to time, mainly with changes in the political regimes. Despite, such changes, overall manufacturing exports have contributed significantly in fostering the growth and generation of employment during the post liberalization period. However, the nation failed to maintain the high growth momentum that was achieved during the early stages of the new development strategy. The pace of growth started to taper off and reached the stage of near stagnation. This situation is more evident during the last 10 years. 
Additionally, it can be argued that the patterns of performance of exports are highly correlated with the changes in economic polices over the years.

Colonial Sri Lanka was an open economy with a few commercial crops, among which tea dominated as the main source of foreign exchange earnings and generation of employment, albeit with high concentration in the upcountry. Even after independence from British rule in 1948, the same economic structure continued until 1956. The post-independence era experienced changes in the structure of the economy with different development strategies adopted in line with the thinking of the political regimes in power. Influenced by the popular development strategy of government intervention in economic activities that was embraced by many developing nations at the time, Sri Lanka also experienced a shift in the development strategy, where the colonial economic structure with an open economy was transformed into a state dominated industrial economy. The period of $1956-1977$ is identified as an era of close economy, where priority was given towards saving foreign exchange against the policy of foreign exchange earnings during the period of colonial economic policies. Many state-owned industries were started under this inward-looking development strategy.

However, the importance of manufacturing exports as a source of foreign exchange was not neglected totally. As a result, partial liberalization efforts were undertaken during 1968-70. As an incentive to promote nontraditional industrial exports, a dual exchange rate system with devaluation was maintained so that export industries can have access to imported inputs for their export industries (Cuthbertson \& Athukorala 1991). This strategy has paid off with manufacturing output recording its highest contribution up to that time. These partial liberalizations ended in 1970, when the new government focused on extending the role of public corporation in economic activities. Private manufacturing firms were absorbed by the government and State Owned Enterprises (SOE's) were set up, with the objectives of increasing output growth, employment and national savings. Like in many developing countries, which followed state dominated inward looking development strategies, Sri Lanka also experienced the same fate of utter failure of its development strategy. Due to the moral hazard associated with state protection and political interference in managing SOEs, they failed to foster innovation, efficiency and productivity, which could have helped them to have strong cash flows. Instead, most of the SOEs became burdens to the government treasury.

Sri Lanka experienced a new era in development strategy starting from late 1977 with a new political regime coming into power with a land slide victory, due mostly to the economic hardships that the nation was engulfed in, with the failure of the previous regime. The new era saw revolutionary changes with the opening up of the economy with drastic liberalisation measures and impressive incentives for private sector economic activities, which were considered as the engines of growth. Trade reforms were the significant element of the new policy package of the first round, from 1977 to 1980. Under the Free Trade Zones (FTZs) 
system, the tariff scheme was revised, restrictions on foreign investments were reduced, and a pack of incentives was provided for domestic and foreign investors to operate in FTZs. The macroeconomic policies were oriented to support the emerging private industrial sector including financial reforms and monetary policy reforms; adjusting interest rates to keep it above inflation, facilitating foreign banks to get established in the country, allowing credit markets to determine interest rates. Exchange rate adjustment is one of the key attributes in policy changes; in nominal terms, the domestic currency was devaluated more than 100 percent. These policies embedded with massive incentives to the private sector strongly affected structural changes. Rapidly growing export oriented manufacturing industries stimulated the economy to grow at a rapid pace with fast expansion in manufacturing exports.

However, the new reforms lost momentum since 1980, as the policy priorities shifted towards huge investment projects that were politically appeasing. The new investment projects affected export-oriented industrialization reforms, particularly the export sector, since massive government expenditure and capital inflows caused the real exchange rate to appreciate significantly. The high domestic inflation due to excessive public-sector expenditure added more fuel to the issue. Further, the prolonged ethnic conflicts that exhausted most of the resources and efforts that could have been utilized for development programmes further deviated the policy focus from the export oriented agenda.

In 1989, a new package of policy reforms was introduced to intensify the export orientation in the country, which is considered as 'The second wave of liberalization'. New reforms included more privatization attempts, of which one of the goals was to maintain a more flexible exchange rate to support investment and exports. Export oriented manufacturing industries grew further and the ratio of manufacturing exports to output increased dramatically in the 1990s. Within manufacturing exports, garments became the dominant segment since early 1990 s and overtook the place that tea had enjoyed for decades, as the major export. More than half of the employment growth during 1980- 1990 was generated through the export oriented manufacturing sector. All in all, export expansion, particularly the manufacturing exports, was the vital source of growth and generation of employment opportunities.

Since 2005, policy priorities were shifted to infrastructure development with the massive construction drive funded mainly with public funds, while conspicuously avoiding any reference to further trade liberalization. Inconsistent macroeconomic policies and improper fiscal policy management, and arbitrary intervention of the monetary authority to prevent the required adjustments in the nominal exchange, in line with other macroeconomic fundamentals, resulted in an appreciation of the real exchange and consequent erosion of the competitiveness of export-oriented production in the economy. Meanwhile, the non-tradable sector was stimulated by the public-sector infrastructure development projects. The manufacturing sector grew at moderate rate, poorly compared to many other sectors of the economy, which resulted in declining its share in the GDP. In contrast, the services sector was booming. More than two third of incremental GDP came predominantly from non-tradable 
sectors such as - construction, transport, utilities, trade and other services - propelled largely by public sector investment (Athukorala 2010). The prominence of the industrial sector started to disappear with drastic policy changes, initiating structural adjustments in the economy. The services sector started to boom, while the manufacturing sector recorded much slower growth compared to the previous two decades of post liberalization. The reverse pattern of the manufacturing export performances, compared to the early two decades of the post liberalization era, is consistent with the changes in policy strategy preferences followed by policy makers in the country.

The persistent erosion of export performance resulted in the ballooning of the trade deficit and consequent deterioration of the overall balance of payment situation of the country. The continuation of policy intervention in the foreign exchange market to prevent required adjustments in the nominal exchange rate, in order to preserve international competitiveness, exacerbated the situation, as it consumed the limited reserves to defend the currency. These developments have culminated in debates as to what factors could promote exports on a sustainable basis. Therefore, it is worth to examine this situation to identify the factors that determine the export performance in Sri Lanka in order to design the most appropriate policies to promote the sector.

\subsection{Macroeconomic Policy and the Real Effective Exchange Rate (REER)}

The REER is a decisive factor in a country's degree of competitiveness in the world market. Any appreciation of the REER signals that the cost of producing tradable goods has increased, while relative prices in the rest of the world are held constant. So, the production has become less cost efficient. Therefore, appreciation of the REER reflects a deterioration of the level of international competitiveness. On the contrary, a depreciation of the REER helps improve the country's degree of international competitiveness. Therefore, when the REER deviates from the optimal level consistent with long equilibrium, it affects the performance of the export sector. Such a disequilibrium in the REER for a longer period of time, leads to economic instability (Willet 1986).

The REER is a function of a number of variables, other than the nominal exchange rate and reflects the significance of each currency in trade as well as relative inflation rates of related nations. Therefore, the changes in the prices of tradable goods, i.e. import tariff, export taxes or the variables that can be influenced the price levels of non-tradable goods i.e. real interest rate, capital controls etc., are all fundamentals of the REER. The basic macroeconomic requirements for sustainable export oriented growth are favorable investment climates and the maintenance of a realistic, competitive real exchange rate (Athukorala \& Rajapairana 2000).

The objective of liberalization policy reforms in Sri Lanka was to deliver such a consistent macroeconomic policy environment to boost the economic growth. The new policy reforms over the past three decades generated significant changes in the macroeconomic policy framework in the country. In new export oriented policy agendas, the REER was given special 
recognition as one of the important macroeconomic variables associated strongly with the external sector balances and consequently with the overall macroeconomic equilibrium.

At the time, there was a dual exchange rate system that had been in operation since 1968. It was replaced by the new unified and managed flowing exchange rate system, under the liberalization policy, to improve international competitiveness. It caused huge initial devaluation within a single year. The rupee was depreciated by 85 percent, from 8.41 to 15.61 (rupees per dollar) in 1978 (Annual Report, Central Bank of Sri Lanka). Under the new system, the exchange rate was allowed to adjust daily with foreign exchange market conditions. In addition to the exchange rate policy, new policy reforms were contained with some prudent macroeconomic policies. Measures were taken to reduce the budget deficit and significant interest rate reforms were introduced to reduce domestic inflation.

However, the eminence of fiscal policy management was despaired without taking long time and started to deliver high inflation. One of the reasons was the government policy to sell some public enterprises that were making losses. The most significant reason was the government's massive public-sector investments, which included irrigation projects, and housing and urban development programmes. The situation was further exacerbated since 1979, as the Central Bank started to use the nominal exchange rate as an "anchor" to control inflation (Athukorala \& Jayasuriya 1994). The level of intervention of the Central Bank in the exchange rate market was gradually increased and the practice of daily determination of the exchange rate was ultimately withdrawn.

Since the early 80 s, the exchange rate policy in the country seemingly failed in supporting the export sector and alternative measures were introduced to stimulate exports. The Export Development Bank was established to provide various incentives to the export sector. Weak institutional and financial constraints were caused as a result of attempting to achieve the expected outcomes through these indirect approaches.

During the 1989-1990 period, several steps were taken to bring macroeconomic stability back by controlling the fiscal deficit and maintaining the real exchange rate at realistic levels, under the cradling-peg system (Athukorala \& Rajapatirana 2000). However, the macroeconomic stability was arrested by huge government expenditure, particularly due to military and defense expenses during this decade.

In 2005, with a new government, the country's policy focus completely deviated from a market-oriented policy attitude to more populist economic policies. The role of the state was reflected as "guiding the markets" (Athukorala \& Rajapatirana 2000). In the macroeconomic policy front, drastic inconsistencies between the exchange rate policy, fiscal policy and monetary policy were shown. Since the nominal exchange rate has multiple effects on key macroeconomic variables that are used to gauge the health of the economy, the Central Bank, in recent times intervened in the foreign exchange market to stabilize the nominal exchange rate, despite it was not being consistent with the prevailing macroeconomic developments. 
With relatively higher inflation compared to competitors and trading partners of the nation, the relatively stable nominal exchange rate which has been created artificially the real exchange rate continued to appreciate.

Subsequent to the end of the civil war that severely affected the political stability in the country for about 30 years, in 2009, the government gave policy priority to infrastructure development projects. Large scale construction and reconstruction were started with massive public sector investments. The widening fiscal deficit was a key attribute in this period that affected macroeconomic stability further.

In addition, a new set of rules and regulations were introduced by enacting the Strategic Development Projects (SDP) Act of 2008 to facilitate the development projects around the country. The objective was to bring multiple benefits to the country through the generation of employment, technology transfer and foreign exchange earnings. The act empowered the minister of economic development and investment promotion to make investment decisions including investment promotion, approving, managing and offering tax concessions, and supervising such projects from beginning to the end (Government of Sri Lanka 2008). This approach reduced the transparency in the investment programmes to a greater extent. Further, the abolition of the GSP-Plus scheme in 2010 also had a significant impact on export oriented manufacturing firms, since they lost duty free access to the European Union for 7200 products. Many foreign investment firms in the manufacturing sector left the country due to the above reasons, during this period (Wickramarachchi 2015). Despite a new set of strategies to attract FDI, there were no significant improvements in manufacturing sector investments or in the setup of the manufacturing sector in the country over the past few years (Athukorala 2012). Thus, in the post war period, there has been notable policy uncertainty relating to the external sector.

Overall, manufactured export performance is positively related to an outward-oriented trade regime during the first two decades of post liberalization reforms (Wignaraja 1998). However, the economy failed to maintain macroeconomic stability overtime. Particularly, during the past ten years, development strategy has not given due priority to promote the export sector. As a result, the composition of the GDP has changed with more prominence of the services sector, while reducing the significance of the manufacturing sector. Sri Lanka's export performance since 2000 has not been a satisfactory one. The expanding trade deficit in 2011 and 2012 is partly explained by the weak performance of the export sector. Further, the global economic downturn is not the only reason for the low export growth in Sri Lanka (Kelegama 2013).

In summary and more importantly, during the past ten years the development strategy has not given due priority to promote the export sector in Sri Lanka. As a result, the composition of the GDP has changed where the services sector has become more prominent, while the significance of the manufacturing sector has faded away gradually. 


\section{The Model}

Most of the previous empirical studies for the determinants of the performance of export sector have concentrated on the formulation of the reduced form of the export equation. Following the traditional way to estimate the sensitivity of exports to the real exchange rate, derived by solving export demand and export supply equations assuming an equilibrium between demand and supply functions of exports $\left(\mathrm{X}_{\mathrm{t}}^{\mathrm{d}}=\mathrm{X}_{\mathrm{t}}^{\mathrm{s}}=\mathrm{EX}_{\mathrm{t}}\right.$ ) (Goldstein \& Khan 1978, 1985; Cerra 1999), this study employs a fully specified reduced form of the export equation to identify the determinants of the performance of manufacturing exports.

Accordingly, the model can accommodate factors of both the demand and supply side. The advantage of the reduced form of the export equation is to avoid simultaneous equation bias, which may arise when estimating a demand or a supply function solely (Goldstein \& Khan 1978).

In the model, total manufacturing exports (excluding petroleum products), which accounted for around 60 percent of total exports in the country, is the dependent variable. The total manufacturing exports are disaggregated into garment and other manufacturing exports. Garment exports from Sri Lanka account for around 70 percent of total manufacturing exports. This has heavy concentration around garments, which is a highly labor-intensive manufacturing good, and justifies the approach of taking that sector separately for the analysis. Accordingly, the study estimates three different models for total manufacturing exports, garment exports and other manufacturing exports, to ascertain whether the degree of the impact of the REER varies among different categories of exports.

The REER, which measures the country's competitiveness in international markets, is the key determinant variable in the study. The real exchange rate (RER) is defined as 'the relative price of tradable with respect to non-tradable goods' (Edwards 1988).

\section{RER $=$ Price of Tradable Goods / Price of non tradable goods}

Since prices of tradable and non-tradable goods are not readily available, the above equation is not usually used in studies. Therefore, the study uses the proximate measure based on the method proposed by Edwards (1988), which is as follows;

$$
\operatorname{REER}_{\mathrm{t}}=\left[\sum \mathrm{S}_{\mathrm{i}} * \mathrm{NER}_{\mathrm{it}} * \mathrm{Pw}_{\mathrm{it}}\right] / \mathrm{Pd}_{\mathrm{t}}
$$

In the given equation, the REER is measured using available domestic and world price indices and the nominal exchange rate. The $S_{i}$ is the export share corresponding to partner $i$. The NER denotes the nominal exchange rate (units of domestic currency per one unit of the currency of country i), $\mathrm{Pw}$ is an index of world prices, which is represented by producer price index of corresponding partner i. Pd is an index of domestic prices. NER and $\mathrm{P}_{\mathrm{w}}$ are weighted averages of the share of trading partners. The measures used for $\mathrm{P}_{\mathrm{w}}$ and $\mathrm{P}_{\mathrm{d}}$ in previous studies are 
different to each other. The proxy for $\mathrm{P}_{\mathrm{w}}$ is usually the whole sale price index. The consumer price index (CPI) has been used in many studies as a proxy for $\mathrm{P}_{\mathrm{d}}$.

A decrease (increase) in the REER index denotes appreciation (depreciation) of the domestic currency with respect to the currencies of trading partners, which impact export performance negatively (positively).

The first controlled variable is the world demand approximated by the real income of importing countries. Manufacturing exports of Sri Lanka are heavily concentrated on the garment exports demand, which is heavily concentrated on a few advanced countries. However, garments of Sri Lanka are competitive in the international markets due to high quality and established brand names. Therefore, it is important to examine whether manufacturing export performance is influenced by the income level of importing nations. Further, any impact due to external shocks on export performance is also indirectly captured by the world demand variable, as the demand of developed countries are more sensitive to such changes and tend to adjust their preferences fast.

The second controlled variable is Foreign Direct Investment (FDI). The FDI has played an important role in establishing and promoting the manufacturing industries in Sri Lanka since the 1980s. The FDI not only contributes to domestic capital formation, but also brings technology, managerial knowhow and marketing channels. Following the market oriented policy reforms, many steps have been taken to attract export-oriented investors. The Board of investment $(\mathrm{BOI})$ is the unique institution that promotes export-oriented investments and also has the power to establish and operate Export Processing Zones (EPZ) in the country, where majority of export oriented manufacturing industries are located. Further, 'several incentive packages were offered to investors in EPZs, allowing complete foreign ownership of investment projects' (Athukorala \& Jayasuriya 2004). In that context, it is worthy to examine the impact of FDI on manufacturing exports.

The third controlled variable is production capacity. In practice, even if all other variables remain unchanged, exports would shift due to the increase in the production capacity of the country. It is important to have a direct measure to capture the production effect of manufacturing on exports, but the data is not available for a long time span. Value added manufacturing is not a good proxy, as export is a small component of total manufacturing. Therefore, the study uses the time trend variable in the model to capture the improvement in the production capacity overtime.

In addition, trade related policy reforms also play a decisive role in exports performance. The empirical evidence proved that manufactured export performance in Sri Lanka is positively related with outward-oriented policy reforms since 1977 (Wignaraja 1998). The policy measures taken during the post liberalization period under different regimes are not limited to the exchange rate policy or relative price adjustments. There have been many institutional changes embedded with various incentive packages for the private sector, in terms of financial 
and non-financial, such as a more secure investment climate, business friendly environment etc. Thus, these policies have contributed to improving export performance by stimulating the private sector to invest in manufacturing exports. The dummy variables REG 1, REG 2, and REG 3 are considered to capture the impact of such policy regime shifts.

The final explanatory (dummy) variable is the MFA that represents the impact of the Multi Fiber Agreement (MFA) that provided quota restrictions on the garment exports. Sri Lanka's garment exports had been largely depended on the MFA Quota facility since 1978. '...the quota system covers more than 52 per cent of the country's garment exports (Dheerasinghe 2009). In the existing literature, the MFA is considered as an important determinant of Sri Lanka manufacturing exports, as garments became Sri Lanka's largest single item of exports since the late $80 \mathrm{~s}$, utilizing the quota facility. Though it is believed that the fast expansion of manufacturing exports is due to the MFA quota system, garment exports continued to maintain its position even after the abolition of the MFA in 2005.

Based on the above discussion, the empirical model used in the study can be specified as follows;

$$
\begin{gathered}
\operatorname{REXP}_{t}=\beta_{0}+\beta_{1} \text { REER }_{t}+\beta_{2} \text { WD }_{t}+\beta_{3} \text { FDI }_{t}+\beta_{4} \text { TIME }_{t}+\beta_{5} \text { REG2 }_{t}+\beta_{6} \text { REG3 }_{t} \\
+\beta_{7} \text { MFA }_{t}+U_{t}
\end{gathered}
$$

Where,

$\begin{array}{ll}\text { REXP } & : \text { Manufacturing exports } \\ \text { REER } & : \text { Real Effective Exchange Rate } \\ \text { WD } & : \text { World demand } \\ \text { FDI } & : \text { Foreign Direct Investments (FDI) } \\ \text { TIME } & \text { Time trend to capture changes in production capacity overtime } \\ \text { REG2 and REG3 } & : \text { Binary dummy variables to capture the changes of policy regime } \\ & \text { related to trade where 1970-1976 (REG1), 1977-2001 (REG2) } \\ & \text { and 2002-2014 (REG3) } \\ \text { MFA } & : \text { Quota facility under Multi Fiber Agreement }\end{array}$

Sign of coefficient of the REER $\beta_{1}$ would depend on the way exports respond to REER appreciation and depreciation. If the REER depreciates (increases), exports increase and if the REER appreciates (decreases), exports decrease. Since there is a positive relationship between the REER and export performance, $\beta_{1}$ will be positive. $\beta_{2}$ will also be positive, as the levels of income of importing countries increase, demand for exports increase. However, if the partners 
are highly focused on export substitution policies though their income increases, they would not increase the demand for exports. This would lead to the yielding of a negative coefficient. FDI and production capacity would generally impact exports positively. Therefore, $\beta_{3}$ and $\beta_{4}$ are expected to be positive. $\beta_{5}$ and $\beta_{6}$ are expected to be positive as it assumes that policy regime shifts help the export sector to operate in a more business friendly environment. The contribution of the quota restriction provided under the MFA agreement to perform manufacturing exports is obvious. Then, the abolition of the MFA in 2005 would have a negative impact on manufacturing export performance, hence $\beta_{7}$ will be positive or negative.

The model is estimated separately for total manufacturing goods exports (EXP), garment exports (GAR) and other (non-garments) manufacturing exports (OTH) due to the reason discussed above. The MFA dummy variable is included only in the total exports and garment export equations, but not in the other export equation.

\section{Data and Sources}

Data for manufacturing exports (EXP) are compiled from the annual reports of the Central Bank of Sri Lanka (CBSL). For constructing the REER series, the producer price index is used for $\mathrm{P}_{\mathrm{w}}$. The weighted average of the $\mathrm{P}_{\mathrm{w}}$ series is constructed based on the export share of six major trading partner countries (US, UK, Germany, France, Italy and India), which account for more than 90 per cent of Sri Lanka's manufacturing exports. The GDP deflator is used as a proxy for $\mathrm{P}_{\mathrm{d}}$ instead of the CPI, since the CPI does not reflect the country-wide price changes and also can be a politically sensitive measure that would deliver wrong results. The base year used in all calculations is 2005. The data on the Nominal Exchange Rates (NER) were obtained from the UNCTAD (United Nations Conference on Trade and Development) site. Producer Price Indices of trading partners and nominal and real GDP data to calculate domestic GDP Deflator were obtained from World Development Indicators (WDI) of the World Bank site. World Demand $\left(\mathrm{W}_{\mathrm{D}}\right)$ is approximated by the real income of trading partners. Data for $\mathrm{W}_{\mathrm{D}}$ has been obtained from the WDI of the World Bank site. All variables in the model other than the dummy variables are used in natural logs. Data and the sources for each variable are summarized in Table 1. The summary statistics are given in Annexure 01 and graphs of data series on logged level are given in Annexure 02. 
Table 1: Data and the Sources

Variable Data $\quad$ Source

\section{MANUEXP}

GAREXP

OTHEXP

REER

WD

FDI

MFA

REG 1 (1970-1976)

REG 2 (1977-2001)
Manufacturing exports

Real Effective Exchange Rate

World Demand : Trade weighted real GDP of trading partners

Foreign Direct Investments : Total value of FDI

Dummy for the non-MFA period
Central Bank of Sri Lanka (CBSL) publications

UNCTAD Statistics, United Nations Conferenc on Trade and Development

World Development Indicator -World Bank

CBSL publications

Based on Literature Survey

REG 3 (2002-2014)

\section{Estimation method}

Since time series data are used in the study, it is necessary to examine whether the variables are stationary or non-stationary. Use of non-stationary data in regressions could produce spurious results through incorrect relationships. Therefore, logarithms of all variables were tested on the univariate basis, using the Augmented Dickey Fuller (ADF) test to examine the presence of unit roots, as proposed by Engle and Granger (1987). First logged level variables were tested and if a unit root for a particular series was found, then they were tested again by taking the first difference level of the series. If a series is stationary at level, the series is called $\mathrm{I}(0)$ and if a series becomes stationary after first differencing, the series is called I(1) series. When the ADF test is conducted, the intercept and trend were included based on the graphical analysis of each series. Table 2 presents the results of the ADF test. 
Table 2: Results of ADF test

\begin{tabular}{lccccc}
\hline \hline \multirow{2}{*}{ Variable } & \multicolumn{2}{c}{ Level } & \multicolumn{2}{c}{ First difference } & \\
\cline { 2 - 5 } & $\begin{array}{c}\text { ADF Test } \\
\text { Statistic }\end{array}$ & $\begin{array}{c}\text { Critical Value } \\
\text { at 5\% Level }\end{array}$ & $\begin{array}{c}\text { ADF Test } \\
\text { Statistic }\end{array}$ & $\begin{array}{c}\text { Critical Value } \\
\text { at 5\% Level }\end{array}$ & $\begin{array}{c}\text { Order of } \\
\text { Integration }\end{array}$ \\
\hline LMANUEXP & -2.896 & -3.54 & -4.672 & -3.54 & $\mathrm{I}(1)$ \\
LGAREXP & -2.638 & -3.54 & -3.729 & -3.54 & $\mathrm{I}(1)$ \\
LOTHEXP & -2.797 & -3.54 & -5.114 & -3.54 & $\mathrm{I}(1)$ \\
LREER & -1.834 & -3.54 & -4.612 & -3.54 & $\mathrm{I}(1)$ \\
LWD & -2.922 & -3.54 & -4.842 & -3.54 & $\mathrm{I}(1)$ \\
LFDI & -3.678 & -3.54 & -2.888 & -3.54 & $\mathrm{I}(0)$ \\
\hline
\end{tabular}

Source : Estimates using Eviews 9.5

Note : $\mathrm{H} 0$ : Series has a unit root, $\mathrm{H} 0$ is rejected at the 5 per cent level

The ADF test results show that one of the independent variables, the FDI, is integrated of order zero $(\mathrm{I}(0))$, while all other independent variables are integrated of order one.

When the export equation (1) above is estimated, it is necessary to estimate the long run relationships among the variables. The long run relationships can be estimated through a conventional co-integration technique, but the technique required all series to be integrated in the same order. According to the results of the unit root test, variables used in the study are a mix of $\mathrm{I}(0)$ and $\mathrm{I}(1)$. Therefore, the Autoregressive Distributed Lags (ARDL) method developed by Pesaran and Shin (1999) and Pesaran (2001) is used in the study.

The ARDL technique provides some additional advantages in the estimation process compared to other estimation methods. First, it allows the use of a mix of $\mathrm{I}(0)$ and/or $\mathrm{I}(1)$ in the ARDL and pre-testing for the unit root is only required to confirm that the series are not of I(2) or a higher order. Second, it supports small and finite samples to deliver statistically significant results compared to other techniques that prefer to have large samples to deliver reliable results. Third, the ARDL technique has the ability of accommodating different time lags for different variables in the model, while other techniques require all variables to be kept in the same order of lag. Fourthly, it takes care of omitted variables and serial correlation problems and addresses any endogeneity problem, since it provides unbiased estimates in the long-run model. Further, the ARDL model estimates both short run and long run dynamics simultaneously in one single reduced form equation (Harris \& Sollis 2003).

The Log linear transformation of the model (1) in the ARDL specification is as follows; 


$$
\begin{aligned}
\Delta \operatorname{Ln}(\operatorname{REXP})_{\mathrm{t}}=\alpha+ & \sum_{\mathrm{k}-1} \psi_{\mathrm{k}} \Delta \operatorname{Ln}(\operatorname{REER})_{\mathrm{t}-\mathrm{k}}+\sum_{\mathrm{k}-1} \gamma_{\mathrm{k}} \Delta \operatorname{Ln}(\mathrm{WD})_{\mathrm{t}-\mathrm{k}}+\sum_{\mathrm{k}-1} \delta_{\mathrm{k}} \Delta \operatorname{Ln}(\mathrm{FDI})_{\mathrm{t}-\mathrm{k}} \\
& +\sum_{\mathrm{k}-1} \lambda_{\mathrm{k}} \Delta \operatorname{Ln}(\operatorname{REXP})_{\mathrm{t}-\mathrm{k}}+\beta_{1} \operatorname{Ln}(\operatorname{REER})_{\mathrm{t}-1}+\beta_{2} \operatorname{Ln}(\mathrm{WD})_{\mathrm{t}-1}+\beta_{3} \operatorname{Ln} \\
& (\mathrm{FDI})_{\mathrm{t}-1}+\beta_{4} \operatorname{Ln}(\operatorname{REXP})_{\mathrm{t}-1}+\beta_{5} \operatorname{TIME}_{\mathrm{t}}+\beta_{6} \mathrm{REG}_{\mathrm{t}}+\beta_{7} \mathrm{REG}_{\mathrm{t}}+\beta_{8} \\
& \mathrm{MFA}_{\mathrm{t}}+\epsilon_{\mathrm{t}}
\end{aligned}
$$

where $\Delta$ indicates the variables are in the first-difference form and $\mathrm{p}$ is the optimal lag length. $\epsilon_{t}$ is the random error term. Coefficients $\beta_{1}, \beta_{2}, \beta_{3}, \beta_{4}, \beta_{5}, \beta_{6}, \beta_{7}$, and $\beta_{8}$ show long term dynamics while $\psi_{\mathrm{k}}, \gamma_{\mathrm{k}}, \delta_{\mathrm{k}}$, and $\lambda_{\mathrm{k}}$ stand for short term dynamics.

The study followed the three stages of the ARDL approach to Cointegration as follows;

First, the orders of the lags in the ARDL model can be selected either by the Akaike information criterion (AIC) or the Schwarz Bayesian criterion (SBC). Since the study used annual data, it used two as the maximum order of lags in the estimations, as Pesaran and Shin (1999) recommended. The AIC (Akaike Information criterion) is used to decide the lag structure of the series.

In the second step, the bound testing approach (Wald test) is employed to examine the existence of a long- run relationship between the variables. Whether to include the long-run dynamics in the model is decided by comparing the F test statistic with the critical values proposed by Pesaran (2001).

The null hypothesis in the $\mathrm{F}$ test is,

$$
\mathrm{HO}: \beta_{1}=\beta_{2}=\beta_{3}=\beta_{4}=\beta_{5}=\beta_{6}=\beta_{7}=\beta_{8}=0
$$

which check against,

$$
\text { H1: } \beta_{1} \neq \beta_{2} \neq \beta_{3} \neq \beta_{4} \neq \beta_{5} \neq \beta_{6} \neq \beta_{7} \neq \beta_{8} \neq 0
$$

The F statistic depends on the number of independent variables in the regression $(\mathrm{k})$, the sample size (n), stationary $\mathrm{I}(0)$ and non-stationary $\mathrm{I}(1)$ properties and whether the estimated model has a trend and/or intercept.

Two sets of critical values are provided by Pesaran (2001); an upper bound critical value (UCB) that is used when all variables in the model are integrated of order I(1), and a lower bound critical value $(\mathrm{LCB})$ that is used when variables are $(\mathrm{I}(0))$. If the calculated $\mathrm{F}$ statistic by the joint test is greater than the upper bound critical value, the variables are said to be cointegrated, where there is a long run relationship in the model.

In the third step, the following long-run model is estimated if there is evidence of a long-run relationship (cointegration) of the variables. 


$$
\begin{aligned}
& \operatorname{Ln}(\operatorname{REXP})_{\mathrm{t}}=\alpha_{1}+\sum_{\mathrm{k}-1} \psi_{1 \mathrm{k}} \operatorname{Ln}(\operatorname{REER})_{\mathrm{t}-\mathrm{k}}+\sum_{\mathrm{k}-1} \gamma_{1 \mathrm{k}} \operatorname{Ln}(\mathrm{WD})_{\mathrm{t}-\mathrm{k}}+\sum_{\mathrm{k}-1} \delta_{1 \mathrm{k}} \operatorname{Ln}(\mathrm{FDI})_{\mathrm{t}-\mathrm{k}} \\
& +\sum_{\mathrm{k}-1} \lambda_{1 \mathrm{k}} \operatorname{Ln}(\mathrm{REXP})_{\mathrm{t}-\mathrm{k}}+u_{\mathrm{t}}
\end{aligned}
$$

The ARDL specification of the short-run dynamics, derived by constructing an Error Correction Model (ECM) is as follows;

$$
\begin{aligned}
& \Delta \operatorname{Ln}(\operatorname{REXP})_{\mathrm{t}}=\alpha_{2}+\sum_{\mathrm{k}-1} \psi_{2 \mathrm{k}} \Delta \operatorname{Ln}(\mathrm{REER})_{\mathrm{t}-\mathrm{k}}+\sum_{\mathrm{k}-1} \gamma_{2 \mathrm{k}} \Delta \operatorname{Ln}(\mathrm{WD})_{\mathrm{t}-\mathrm{k}}+\sum_{\mathrm{k}-1} \delta_{2 \mathrm{k}} \Delta \operatorname{Ln}(\mathrm{FDI})_{\mathrm{t}-\mathrm{k}} \\
& +\sum_{\mathrm{k}-1}^{\mathrm{P}_{2}} \lambda_{2 \mathrm{k}} \Delta \operatorname{Ln}(\mathrm{REXP})_{\mathrm{t}-\mathrm{k}}+\mathrm{\gamma} \mathrm{ECM}_{\mathrm{t}-1}+\rho_{\mathrm{t}} \\
& \mathrm{ECM}_{\mathrm{t}}=\operatorname{Ln}(\operatorname{REXP})_{\mathrm{t}}-\alpha_{1}-\sum_{\mathrm{k}-1}^{\mathrm{P}_{1}} \psi_{1 \mathrm{k}} \operatorname{Ln}(\mathrm{REER})_{\mathrm{t}-\mathrm{k}}-\sum_{\mathrm{k}-1}^{\mathrm{P}} \gamma_{1 \mathrm{k}} \operatorname{Ln}(\mathrm{WD})_{\mathrm{t}-\mathrm{k}}-\sum_{\mathrm{k}-1}^{\mathrm{P}_{\mathrm{j}}} \delta_{1 \mathrm{k}} \operatorname{Ln}(\mathrm{FDI})_{\mathrm{t}-\mathrm{k}} \\
& \text { - } \sum_{\mathrm{k}-1}^{\mathrm{P}_{\mathrm{k}}} \lambda_{1 \mathrm{k}} \operatorname{Ln}(\mathrm{REXP})_{\mathrm{t}-\mathrm{k}}
\end{aligned}
$$

In the short-run equation, all coefficients are related to the short-run dynamics of the model's convergence to equilibrium and $\mathrm{\gamma}$ represents the speed of adjustment.

Following the methodology above, the study estimates three different models; for Total Manufacturing Exports (MANUEXP), Garment Exports (GAREXP) and Other Exports (OTHEXP).

After estimating the models, the residual of all selected models are tested for unit root, to check whether they are stationary at level, which further confirms the long run equilibrium that exists among variables.

Further, the most common and standard residual diagnostics tests i.e. Serial Correlation LM test and Breusch-Pagan-Godfrey test for Heteroskedasticity were performed. In addition, the other standard residual diagnostic tests were performed to confirm the validity of the estimated model. Further, the stability of the system is tested by the CUSUM test.

\section{Results}

The prime objective of the study is to examine the impact of the REER on export performance. As the first step, bivariate models for all three categories of exports are estimated. However, the TIME variable had to be included in the models in order to preserve the fitness and stability of the models. AIC is used to determine the optimal number of lags to be included in the models. The lag length that minimizes AIC is one for all three models. The Model selection summary output is given in Annexure 03.The summary of the bivariate model estimations is given in Table 3. 
Table 3: Bivariate Models

\begin{tabular}{|c|c|c|c|}
\hline Variable & MANUEXP & GAREXP & OTHEXP \\
\hline \multirow[t]{2}{*}{ C } & -0.549 & -1.224 & 0.160 \\
\hline & $(0.704)$ & $(1.083)$ & $(0.152)$ \\
\hline \multirow[t]{2}{*}{ D(LREER) } & $0.777 * * *$ & $0.301 * *$ & $0.470^{* *}$ \\
\hline & $(2.814)$ & $(2.056)$ & $(1.911)$ \\
\hline \multirow[t]{2}{*}{ D(LREER(-1)) } & -0.185 & $0.629 *$ & 0.205 \\
\hline & $(0.465)$ & $(1.941)$ & $(0.518)$ \\
\hline \multirow[t]{2}{*}{ D(LEXP(-1)) } & $0.516^{* * *}$ & 0.105 & $0.132^{* *}$ \\
\hline & (3.773) & $(0.743)$ & $(1.919)$ \\
\hline \multirow[t]{2}{*}{ LREER(-1) } & $0.403^{* *}$ & 0.426 & $0.330^{* *}$ \\
\hline & $(2.076)$ & $(1.422)$ & $(2.172)$ \\
\hline \multirow[t]{2}{*}{ LEXP(-1) } & $0.475^{* * *}$ & 0.149 & $0.285^{* * *}$ \\
\hline & (3.434) & $(1.352)$ & $(3.570)$ \\
\hline \multirow[t]{2}{*}{ TIME } & $0.028^{* * *}$ & 0.015 & $0.0135^{*}$ \\
\hline & $(3.067)$ & $(1.392)$ & $(1.768)$ \\
\hline$R^{2}$ & 0.466 & 0.488 & 0.530 \\
\hline Adj. $\mathrm{R}^{2}$ & 0.377 & 0.403 & 0.452 \\
\hline F stat & 5.238 & 5.719 & 6.779 \\
\hline$S E$ & 0.236 & 0.169 & 0.238 \\
\hline$D W$ & 2.068 & 1.879 & 2.037 \\
\hline LMS-F & 0.808 & 0.348 & 0.487 \\
\hline$J B N$ & 30.995 & 1.896 & 3.567 \\
\hline HSC & 1.645 & 3.219 & 1.632 \\
\hline
\end{tabular}

Level of statistical significance: $*=10 \%, * *=5 \%, * * *=1 \%$

t-statistics are given in parenthesis.

The short-run coefficient of the REER is significant in all three cases. However, the study is more focused on the impact of long run dynamics in models, as long run impacts are more favorable to analyse the issue. 
In the long-run, garment exports do not respond to the changes in the REER. The impact of the REER on the total manufacturing exports and other exports is positive and highly significant. If the REER depreciated by 1 percent, total manufacturing exports and other exports would increase by 0.4 and 0.33 percent, respectively.

In the second step, the full models were estimated for Total Manufacturing Exports (MANUEXP), Garment Exports (GAREXP) and Other Exports (OTHEXP), including the REER and all other controlled variables.

Policy regime dummies (REG 2, REG 3) are included in the original model (1) to capture any other impact due to regime shifts other than the REER related policies, i.e., economic stability, institutions, investment perception and secure business environment. However, regime shift dummies in the full model are highly correlated with the REER variable and the models were not sufficiently fit and stable. The movements of the REER during the past few decades show a distinctive pattern in line with the changes in policy regimes. In all three policy regimes, there were significant policy implications on the REER causing it to depreciate or appreciate. Accordingly, the model (1) is estimated excluding regime shift variables (REG 1 and REG 2).

The optimal number of lags to be included in the models were decided based on AIC. The model selection summary output is given in Annexure 04. The best three models for MANUEXP, GAREXP and OTHEXP were selected using the co-integration analysis and all the diagnostic test results are presented below.

The bound tests proved the existence of a long- run relationship among the variables in the selected three models. The F test statistics for the selected three different models and the relevant lower and upper bound critical values from Pesaran (2001) table are reported in Table 4 below.

Table 4 : F Test Statistics and Bound Test Results

\begin{tabular}{ccc}
\hline \hline Models & F Statistics & P Value \\
\hline MANUEXP & 11.191 & $0.000^{* * *}$ \\
GAREXP & 5.765 & $0.000^{* * *}$ \\
OTHEXP & 5.300 & $0.000^{* * *}$ \\
$* 5 \%$ significant level & LCB & UCB \\
& 3.23 & 4.35 \\
\hline
\end{tabular}

Source: Pesaran (2001), Table CI(iii) Unrestricted intercept and no trend 
Test statistics of all three models lie outside UCB and LCB values and exceed the UCB critical value. Therefore, the null hypothesis is rejected in favour of the alternative and it can be concluded that there are long-run relationships in all three models.

The residual of all three models were tested for unit root tests and test results revealed that residuals are stationary at level, which further confirmed the long run equilibrium that exists among variables. The results of the Serial Correlation LM test and Breusch-Pagan-Godfrey test for Heteroskedasticity confirmed that there is no Serial Correlation in the systems and also no heteroskedasticity is present in all three cases. The residual diagnostic test results for the selected three models are given in Table 5 .

Table 5: Residual Diagnostic Test Results

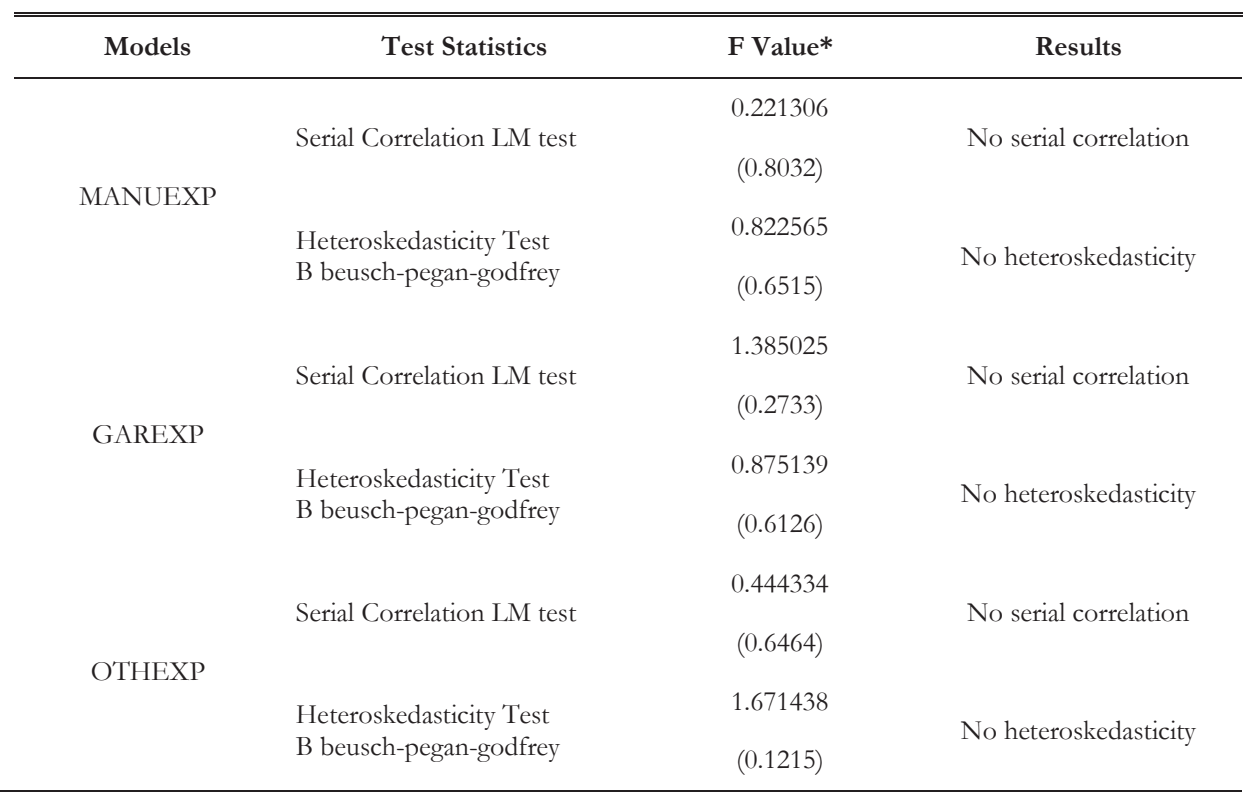

Values in the Parenthesis are the P-values

The CUSUM test results revealed that all three systems are stable. Figure 1 presents the plots of the CUSUM statistics for three models that fall inside the critical bands at $5 \%$ confidence interval. 


\section{Figure 1: CUSUM test results}

Model for MANUEXP

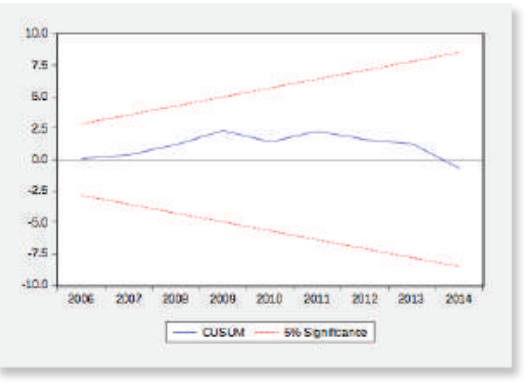

Model for GAREXP

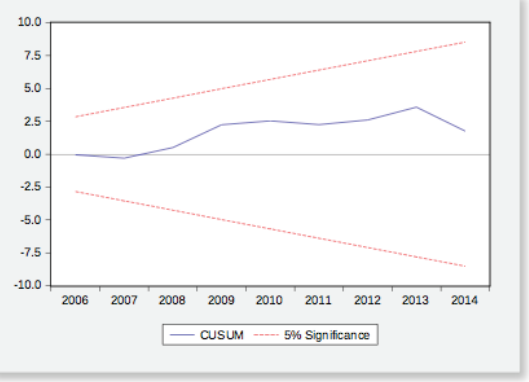

Model for OTHEXP

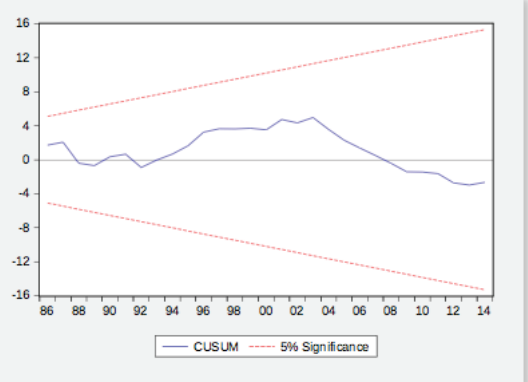

Based on the results of the co-integration analysis and the diagnostic tests, the three models that were selected as the most preferred models in the study are as follows. 
Table 6: The Short Run Dynamics: Error Correction Representation for the selected ARDL Models

\begin{tabular}{|c|c|c|c|}
\hline & MANUEXP & GAREXP & OTHEXP \\
\hline \multirow[t]{2}{*}{ CONS } & $-61.118^{* * *}$ & - & $-27.526^{* *}$ \\
\hline & (4.892) & & $(2.276))$ \\
\hline \multirow[t]{2}{*}{ D(LREER) } & - & - & $-0.781 *$ \\
\hline & & & $(1.790)$ \\
\hline \multirow[t]{2}{*}{ D(LREER(-1)) } & $0.950 * *$ & -0.473 & -0.243 \\
\hline & $(2.211)$ & $(1.462)$ & $(0.559)$ \\
\hline \multirow[t]{2}{*}{ D(LREER(-2)) } & $1.219^{* *}$ & -0.590 & -0.789 \\
\hline & $(2.540)$ & (1.937) & $(1.372)$ \\
\hline \multirow[t]{2}{*}{ D(LWD) } & $7.103^{* * *}$ & $2.635^{* *}$ & $8.402^{* * *}$ \\
\hline & (4.133) & $(2.962)$ & $(3.895)$ \\
\hline \multirow[t]{2}{*}{ D(LWD(-1)) } & -0.764 & $3.272^{* *}$ & - \\
\hline & $(0.417)$ & (2.901) & \\
\hline \multirow[t]{2}{*}{$\mathrm{D}(\mathrm{LWD}(-2))$} & 1.831 & $-2.207 *$ & - \\
\hline & (1.032) & (2.083) & \\
\hline \multirow[t]{2}{*}{ D(LFDI) } & - & $0.171 * * *$ & - \\
\hline & & (3.183) & \\
\hline \multirow[t]{2}{*}{ D(LFDI(-1)) } & $0.172^{* *}$ & $0.330^{* * *}$ & $0.237 * *$ \\
\hline & (2.109) & (5.684) & $(2.386)$ \\
\hline \multirow[t]{2}{*}{ D(LFDI(-2)) } & - & $0.170^{* * *}$ & - \\
\hline & & (3.669) & \\
\hline \multirow[t]{2}{*}{ D(LEXP(-1)) } & $0.642 * * *$ & $-0.654 * * *$ & $0.258^{*}$ \\
\hline & (5.4888) & $(4.527)$ & $(1.910)$ \\
\hline \multirow[t]{2}{*}{$\mathrm{D}(\operatorname{LEXP}(-2))$} & $0.325^{* *}$ & -0.222 & $0.272^{*}$ \\
\hline & $(2.218)$ & (1.638) & (1.944) \\
\hline \multirow[t]{2}{*}{ TIME } & -0.009 & $0.027 * *$ & -0.009 \\
\hline & $(0.372)$ & $(2.190)$ & $(2.089)$ \\
\hline MFA & -0.389 & -0.887 & - \\
\hline
\end{tabular}




\begin{tabular}{lccc} 
& $(3.012)$ & $(1.260)$ & \\
$\operatorname{ECM}(-1)$ & $-0.2786^{* * *}$ & $-0.370 * * *$ & $-0.392^{* * *}$ \\
& $(5.071)$ & $(3.592)$ & $(3.897)$ \\
$R^{2}$ & 0.815 & 0.905 & 0.686 \\
Adj. $\mathrm{R}^{2}$ & 0.718 & 0.850 & 0.556 \\
F stat & 8.478 & 20.443 & 5.281 \\
SE & 0.155 & 0.085 & 0.199 \\
DW & 2.195 & 1.871 & 2.181 \\
LMS-F & 6.000 & 0.172 & 0.236 \\
RESET & 0.055 & 0.034 & 0.082 \\
& & & 0.234 \\
HSC & 0.766 & 0.471 & \\
\hline
\end{tabular}

Level of statistical significance: $*=10 \%, * *=5 \%, * * *=1 \%$

t-statistics are given in parenthesis.

The results of the ECM for the three export categories are presented in Table 6 and the longrun estimations given in Table 7.

In all three models, coefficients of error correction terms (ECM (-1) are negative and highly significant at a $1 \%$ level. The absolute value of coefficient of (ECM (-1) indicates the rate of convergence to equilibrium or the speed of adjustment to equilibrium following a short run shock. Accordingly, the whole system of manufacturing exports will get back to the long-run equilibrium at the speed of 28 per cent. The systems for garment exports and other exports will move to the long-run equilibrium at the speed of 37 per cent and 39 per cent, respectively. These results provide the evidence of co-integration (long-run relationship) among variables in all three models. 
Table 7: The Long Run Estimation Results

\begin{tabular}{lccc}
\hline \hline & MANUEXP & GAREXP & OTHEXP \\
\hline LREER(-1) & $1.129^{* *}$ & $3.373^{* *}$ & $2.109 * *$ \\
& $(2.103)$ & $(1.816)$ & $(1.955)$ \\
LWD(-1) & $5.338^{* *}$ & $-0.758^{* *}$ & $3.876^{* *}$ \\
& $(5.950)$ & -1.474 & $(2.206)$ \\
LFDI(-1) & -0.089 & -0.055 & $-0.089 * *$ \\
& $(1.269)$ & $(0.197)$ & $(0.638)$ \\
TIME & -0.013 & $0.141 * *$ & -0.0216 \\
& $(0.372)$ & $(2.551)$ & $(0.365)$ \\
MFA & $-0.509 * * *$ & -0.459 & - \\
& $(3.487)$ & $(1.394)$ & \\
\hline
\end{tabular}

Level of statistical significance: $*=10 \%, * *=5 \%, * * *=1 \%$

t-statistics are given in parenthesis.

In the short-run, coefficients of the REER are positive and significant only in the total manufacturing equation and the REER is not statistically significant in other two cases. However, in the long-run the REER is significant at a 5 per cent level and also reported a positive sign in all three categories of exports. A one percent depreciation of the REER would lead to the increase of exports by more than one percent in the long-run, which creates a more elastic situation.

The short-run coefficients of WD are positive and significant in all three models and relative sizes of the coefficients show that WD is the dominant determinant of manufacturing exports from Sri Lanka. The results are considerably similar with the long-run results, except for the garment exports. In the long-run, WD is significant with the negative sign in the garment export equation, suggesting that the garment industry has the potential of capturing the markets with upper income by improving the quality standards and catering to globally branded products.

In contrast to the positive and significant impact of FDI on all three types of exports in the short-run, FDI has no significant impact on total manufacturing exports and garment exports in the long-run and also reported a negative sign in all three cases. This confirms that Sri Lanka has failed to utilize FDI flows to improve the export-oriented manufacturing industries during the last few decades. Despite many incentive packages offered to attract investments over the years, the investment climate has not been attractive to foreign investors in export oriented manufacturing industries. The possible reasons may be political instability, policy uncertainty and inefficient institutional structures in terms of FDI promotion and facilitation. 
The Coefficient of TIME variable, which captures the improvement in production capacity, is expected to be positive, assuming that exports will increase due to improvements in production capabilities over time, even though there are no other factors that facilitate the export sector. However, the impact is not significant with respect to the total manufacturing exports and other exports.

The dummy used for the MFA has no significant impact on garment exports in both the shortrun and long-run, which implies that the abolition of the MFA in 2005 had no significant impact on the export performance. It is sensible, because the garment industry had been diversified to non-quota categories of high value products and had been able to establish strong market links. Moreover, the garment industry in Sri Lanka has already been well established and has become internationally competitive due to trade and investment liberalization reforms that have been implemented over the past three decades (Athukorala \& Ekanayake 2015).

Results clearly suggest that the REER has been a key determinant of export performance of the country. According to the overall estimations, it can be suggested that domestic supply side related factors are important in determining the export performance as well as the factors associated with external demand factors.

\section{Conclusion}

The results clearly suggest that the REER has been a key determinant of manufacturing exports of Sri Lanka. Policy makers should aim at maintaining the REER at a realistic (marketconsistent) level to reap such benefits. In order to restore international competitiveness, the nominal exchange rate should be allowed to adjust to the equilibrium level, which needs a significant depreciation. However, nominal depreciation itself will not achieve the objective; it is crucial to maintain domestic macro- economic stability, as it impacts the objective through the relative prices. Results also suggest that Sri Lanka has the ability to penetrate the world market through improvements in supply side competitiveness.

In the current economic conditions of a nation with a large deficit of trade and current account balances of the Balance of Payments, and a significantly higher ratio of foreign debt, nominal depreciation alone would not resolve the problem of those imbalances, since it also would be an expensive instrument, that would worsen government budgetary conditions further. It could also lead to sudden capital outflows due to adverse effects on investor sentiment. Therefore, a more prudent consolidated policy package is required, including a more flexible exchange rate policy and more disciplined fiscal management system to reduce public debt in a sustainable manner. Moreover, a more consistent but independent monetary policy framework, and trade and investment policy reforms are necessary to improve the overall economic condition in the country and foster sustainable growth. 


\section{References}

Athukorala P \& Jayasuriya S 2015, 'Victory in W ar and Defeat in Pace: Politics and Economics of Post-Conflict Sri Lanka’, Asian Economic Papers, Vol.14, No.3, pp. 22-54.

Athukorala P \& Rajapatirana S 2000, 'Liberalization and industrial transformation: Lessons from the Sri Lankan Experience’. Economic Development and Cultural Change, Vol.48, No. 3, pp. 543-573.

Athukorala P \& Ekanayake R 2015, 'Repositioning in the Global Apparel V alue Chain in the PostMFA Era: Strategic Issues and Evidence from Sri Lanka', Colombo: Institute of Policy Studies.

Athukorala P \& Riedel J 1997, Modelling NIE Exports: Aggregation, Quantitative Restrictions and Choice of Econometric Methodology,' Journal of Development Studies, Vol.33, No.1, pp. 81-98.

Athukorala, P 2012, 'Sri Lanka's trade policy; Reverting to dirigisme?', The World Economy, vol.35, no. 12, pp. 1662-1686.

Central Bank of Sri Lanka, Annual Report, Colombo, Sri Lanka, various issues.

Dheerasinghe R 2009, 'Garment Industry in Sri Lanka Challenges, Prospects and Strategies', Central Bank of Sri Lanka, Staff Studies, Vol.33, No.1, pp.33-72.

Edwards S 1989, 'Real Exchange Rates, Devaluation and Adjustment: Exchange Rate Policies in Developing Countries', Cambridge.

Edwards S 1988, 'Real and Monetary Determinants of Real Exchange Rate Behaviour: Theory and Evidence form Developing Countries', Journal of Development Economics, Vol. 29, pp.311-341.

Ekanayake EM 1999, 'Real Exchange Rate Volatility and Sri Lanka's Exports to the Developed Countries, 1978-96', Journal of Development Economics, Vol. 24, No. 1, pp. 147-165.

Export Development Board in Sri Lanka 2015, Performance of the Export Sector in Sri Lanka 2014', Export Development Board in Sri Lanka.

Fang WS et al 2006, 'Export Promotion through Exchange Rate Changes: Exchange Rate Depreciation or Stabilization?', Southern Economic Journal, vol. 72, No. 3, pp. 611-626.

Government of Sri Lanka, 2008, Strategic development projects act, no. 14 of 2008, Government Publication Bureau, Colombo.

Grobar LM 1993, 'The effect of real exchange rate uncertainty on LDC manufactured exports', Journal of Development Economics, Vol. 41, pp.367-376.

Harris, R \& Sollis, R 2003, Applied time series modelling and forecasting, West Sussex: Wiley.

Hinkle LE \& Monteil PJ 1999, 'Exchange Rate misalignment: Concepts and Measurement for Developing Countries', Oxford University, New York, United States. 
Krugman, P. (1986), 'Pricing to Market When the Exchange Rate Changes', NBER Working Paper 1926, National Bureau of Economic Research, Cambridge, MA.

Rodrik D 2008, 'Disequilibrium Exchange Rates as Industrialization Policy', Journal of Development Economics, Vol. 23, No. 1, pp. 89-106.

Pesaran, M \& Shin, Y 1999, 'An autoregressive distributed lag modeling approach to cointegration analysis', in S Strom (ed), 'Econometrics and economic theory in the 20th century: The Ragnar Frisch centennial symposium’, Cambridge: Cambridge University Press, pp. 371-413.

Pesaran, M 2001, 'Bounds testing approaches to the analysis of level relationship', Journal of Applied Economics, vol. 16, no.3, pp. 289-326.

Schatz, H. J. and D. G. Tarr (2002), 'Exchange Rate Overvaluation and Trade Protection', in B. Hoekman, P. English, and A. Mattoo (eds.), Development, Trade, and the WTO: A Handbook, Washington DC: World Bank. Willet T 1986, 'Exchange Rate Volatility, International Trade, and Resource Allocation', Jounal of International money and Finnace, Vol.5, pp.101-112.

Wickramarachchi V D 2015, Determinants of Foreign Direct Investment (FDI) in Developing Countries: The Case of Sri Lanka',

Wignaraja, G. (1998), Trade Liberalization in Sri Lanka: Exports, Technology and Industrial Policy, London: Macmillan Press, 1998 and New York: St. Martins Press. 


\section{Annexures}

Annexure I: Descriptive Statistics

$\begin{array}{lcccccc} & \begin{array}{c}\text { LMANUEX } \\ \multicolumn{1}{l}{}\end{array} & \begin{array}{c}\text { LGAREX } \\ \mathbf{P}\end{array} & \text { LOTHEXP } & \text { LREER } & \text { LWD } & \text { LFDI } \\ \text { Mean } & 5.756 & 4.913 & 4.932 & 4.501 & 14.340 & 5.682 \\ \text { Median } & 6.645 & 6.272 & 5.430 & 4.591 & 14.326 & 6.498 \\ \text { Maximum } & 9.239 & 8.765 & 8.218 & 4.821 & 14.961 & 8.595 \\ \text { Minimum } & -2.303 & -3.507 & -2.659 & 3.984 & 13.673 & -1.661 \\ \text { Std. Dev. } & 3.082 & 3.642 & 2.800 & 0.247 & 0.396 & 3.261 \\ \text { Observations } & 45 & 45 & 45 & 45 & 45 & 45\end{array}$

\section{Annexure II : Logged Level Time Series}

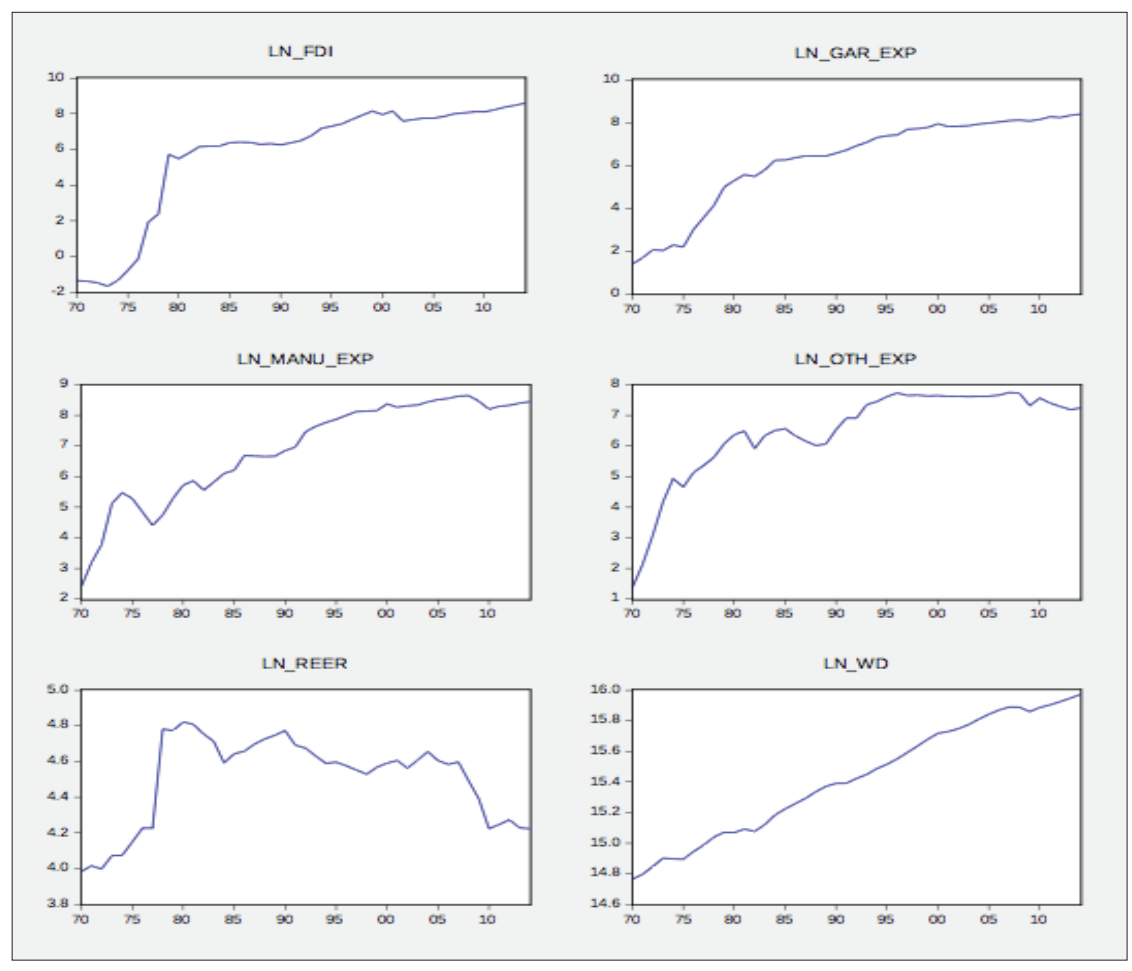




\section{Annexure III : Bivariate Models -Model Selection Summery Output}

\begin{tabular}{lccccc}
\hline \hline Models & Lag Length & AIC & SIC & DW & Wald F. \\
\hline ARDL(MANUEXP,REER) & $(2,2)$ & 0.2357 & 0.5667 & 1.6012 & 4.8575 \\
& $(1,1)^{*}$ & 0.0990 & 0.3857 & 2.0685 & 5.9778 \\
& $(2,1)$ & 0.1724 & 0.5034 & 1.6121 & 4.9408 \\
& $(1,2)$ & 0.1888 & 0.4778 & 1.5857 & 5.8720 \\
ARDL(GAREXP,REER) & $(2,2)$ & -0.5156 & -0.1846 & 1.8495 & 2.2177 \\
& $(1,1)^{*}$ & -0.5666 & -0.2799 & 1.8795 & 1.9727 \\
& $(2,1)$ & -0.4955 & -0.1646 & 1.7176 & 1.7695 \\
& $(1,2)$ & -0.5415 & -0.2519 & 1.9700 & 2.1245 \\
& $(2,2)$ & 0.1799 & 0.5109 & 1.9032 & 6.5470 \\
& $(1,1)^{*}$ & 0.1192 & 0.4059 & 2.0377 & 9.2199 \\
& $(2,1)$ & 0.1524 & 0.5031 & 1.8121 & 6.8408 \\
& $(1,2)$ & 0.2485 & 0.4758 & 1.6367 & 8.8720 \\
\hline
\end{tabular}

* The models selected based on AIC 


\section{Annexure IV: Multivariate Models - Model Selection Summery Output}

\begin{tabular}{|c|c|c|c|c|c|}
\hline Models & Lag Length & AIC & SIC & DW & Wald F. \\
\hline \multirow{5}{*}{$\begin{array}{l}\text { ARDL(MANUEXP,REER,WD } \\
\text {,FDI) }\end{array}$} & $(2,2,2,2)$ & -0.6671 & 0.0776 & 2.3446 & 16.4763 \\
\hline & $(2,2,2,1)^{*}$ & -0.7133 & -0.0099 & 2.3446 & 17.1324 \\
\hline & $(1,1,0,1)$ & -0.1288 & 0.4037 & 2.3443 & 6.0846 \\
\hline & $(1,1,1,1)$ & 0.0206 & 0.5121 & 2.1858 & 7.1387 \\
\hline & $(2,2,0,1)$ & -0.6622 & -0.1244 & 2.1107 & 16.3312 \\
\hline \multirow{5}{*}{$\begin{array}{l}\text { ARDL(GAREXP,REER,WD,F } \\
\text { DI) }\end{array}$} & $(2,2,2,2)^{*}$ & -1.8179 & -1.1559 & 1.8712 & 7.1452 \\
\hline & $(1,1,1,1)$ & -1.3262 & -0.7937 & 2.3614 & 4.3354 \\
\hline & $(1,1,0,1)$ & -1.3832 & -0.9326 & 2.4977 & 4.8029 \\
\hline & $(1,2,2,2)$ & -1.7673 & -1.1467 & 1.8332 & 6.2356 \\
\hline & $(1,0,2,2)$ & -1.7209 & -1.1417 & 1.6861 & 5.1539 \\
\hline \multirow{5}{*}{$\begin{array}{l}\text { ARDL(OTHEXP,REER,WD,F } \\
\text { DI) }\end{array}$} & $(2,2,2,2)$ & -0.0643 & 0.6390 & 1.8791 & 6.6842 \\
\hline & $(1,1,1,1)$ & -0.0067 & 0.5257 & 2.4094 & 4.7779 \\
\hline & $(1,1,0,1)$ & -0.0508 & 0.4407 & 2.3712 & 4.9208 \\
\hline & $(2,2,0,1) *$ & -0.1419 & 0.3960 & 2.2814 & 6.9621 \\
\hline & $(2,2,1,1)$ & -0.1380 & 0.3998 & 2.2845 & 6.6150 \\
\hline
\end{tabular}

* The models selected based on AIC 